九州大学学術情報リポジトリ

Kyushu University Institutional Repository

Studies On The Protein Of Soy Bean : The

Effects Of Neutral Salts of Low Concentration On The Stability of Soy Bean Protein Dispersed In Water

Funatsu, Masaru

Biochemical Laboratory, Department of Agriculture, Kyushu University

https://doi.org/10.5109/22623

出版情報: 九州大学大学院農学研究院紀要. 9 (2)，pp. 185-202，1949-05. Kyushu University バージョン：

権利関係 : 


\section{STUDIES ON THE PROTEIN OF SOY BEAN \\ The Effects of Neutral Salts of Low Concentration on the Stability of Soy Bean Protein \\ DISPERSED IN WATER}

\section{Masaru Funatsu}

\section{INTRODUCTION}

It is well known that the effects of electrolytes on protein sol show a remarkable difference depending upon their concentration. As has been shown by Graham, the aggregation of protein on flocculation is quite different from that on salting-out.

Especially a protein sol which consists of two or more kinds of protein shows a particular behavior toward the electrolytes. In such a protein sol flocculation of protein takes place in a different manner from a simple protein sol depending upon the proportion of its protein components. ${ }^{1)}$. As Plötner ${ }^{2)}$ has already reported, serum shows an inconsistent stability toward sulfosalicylic acid depending upon the proportion of globulin to albumin in serum. Moreover, the proportion of lactalbumin to casein in milk càn easily account for the fact that various kinds of milk have different stability to acid or repnin. ${ }^{3)}$

Now, on extraction of soy bean meal with distilled water, the greater parts of globulin will dissolve in combination with salt in meal. Thus we obtain a polyphase protein colloid, in which two types of protein, i.e., globulin of lyophobic nature and albumin and proteose of lyophilic nature, disperse in water containing minute quantities of salts derived from soy bean meal. In this 
solution proteins are negatively charged by adsorbing the electrolytes derived from soy bean and are in a state of soscalled unsaturated colloid practically identical with soil colloid, because, as later mentioned, the quantity of all the metal ions is not enough to saturate the protein particles. The protein sol in the watery extract of soy bean may not be considered pure sol, since various organic substances in soy bean are extracted with distilled water together with the protein.

Therefore, for studying the dispersion-state of protein particles, at first, it must be decided, whether or not we can use the extract as a pure protein sol. Experiment has shown that it is not unreasonable to treat the extract as a pure sol so far as present studies are concerned.

On adding neutral salts to this protein sol, it was observed that flocculation, which occurs due to the unstable colloidal state of globulin, takes place at about $0.04 \mathrm{Mol}$. concentration of salt in different ways depending upon the proportion of albumin to globulin. This phenomenon can be clearly explained by the protective action of albumin against the flocculation of globulin. This result, furthermore, has been verified by an experiment, in which egg albumin used instead of soy bean albumin produced the same effect on the flocculation. Nevertheless, the mechanism of the protective action of one protein against the other has never been fully explained.

The present paper deals with the discussion of the mechanism from the point of view of hydration under the assumption that the adsorbed albumin plays the same rôle as bound water against the globulin particle.

\section{EXPERIMENTAL METHOD}

\section{Preparation of soy bean protein}

Crush the Manchurian ycllow soy bean by hammer crusher, avoiding heating as much as possible. After removing the testa by wind, extract the lipoids with ether and further grind it into fine powder by mortor.

Extract the protein of this soy bean meal by shaking with 50 times its weight of distilled water for two hours in room tempera- 
ture $\left(24-25^{\circ} \mathrm{C}\right)$. Centrifuge the extract $(3000 \mathrm{r} . / \mathrm{min} ., 30 \mathrm{~min}$.$) , filter$ the supernatant of extract under suction through the filterpulp 2 $\mathrm{cm}$. thick. The clear filtrate contained $1.17-1.20 \mathrm{mg}$ nitrogen in c.c. and its $\mathrm{pH}$ value was 6.4-6.5.

Estimation of the relative turbidity of sol $^{4}$

The state of dispersion, that is, the state of aggregation of protein particle due to the addition of salt was concluded from its relative turbidity. And the relative turbidity of sol has been estimated by measuring, its Tyndall light, since at a constant concentration of protein the strength of Tyndall light of sol is proportional to the volume of particle within a certain range of size of particle. This fact is clearly seen from the formula of Rayleigh :

$$
\mathrm{I}=\mathrm{k} \frac{\mathrm{nv}^{2}}{\lambda^{4}}=\mathrm{k} \frac{\mathrm{c} \mathrm{v}}{\mathrm{d} \lambda^{4}}
$$

The measurement of the strength of Tyndall light has been made by means of Pulflich's Step Photometer (for turbidity) with filter $\mathrm{L}_{2}$ and milky filter No. 4 for standard light, unless otherwise mentioned.

The values of relative turbidity of sol were represented with the strength of Tyndall light, I. For the convenience of the direct comparison between those of various sol, the proportion of the relative turbidity of each sol to a standard sol without any addition of salt was calculated and expressed as RV.

-Measurement of viscosity ${ }^{5}$

The relative viscosity of the sol was determined by using Ostwald's viscosimeter. The viscosity of protein sol does not conform to the formula of Einstein-Smoluchowski: $\eta_{s}=\eta_{0}(1+K \varphi)$ and gives extremely high value. This abnormality in viscosity chiefly depends upon the high hydration of protein particle and has been shown by a value of $\left(\eta_{s}-\eta_{0}\right) / \eta_{0}$ according to Kruyt et al.

By the addition of electrolytes the electrical charge of particle changes due to the charge of electrolyte ions and the increase of relative viscosity can be represented by following value $\left(\gamma_{s+e}-r_{e}\right) / r_{e}$ where, $\eta_{s+e}$ the viscosity of sol added to the electrolyte and $\eta_{i e}$ the viscosity of dispersed medium after the addition of salt. 


\section{EXPERIMENTAL RESULTS AND DISCUSSION}

I. Can soy bean protein sol be used interchangeably with the pure protein sol?

The soy bean protein sol contains various organic substances derived from soy bean meal. It is considered that the organic substances besides protein produce more or less changes on the properties of protein sol.

If the extent of the influence of other organic substance besides protein is not great as to change the colloidal behavior of protein particle or to change the relationship between the values of each components of Rayleigh's formula, we may deal with the pure one. By these means, it must be decided whether or not the value for I $\lambda^{4}$ of these sols, which have equal concentration of protein, may be maintained always constant to various wave lengths of light, as is required by the formula of Rayleigh. Table 1 clearly shows the values for I $\lambda^{4}$ remain constant irrespective of the wave length of light. Hence, it follows that protein sol behaves just like a pure protein sol in spite of the co-existance of other organic substances.

Table 1. I $\lambda^{4}$ value of soy bean protein sol (at $25^{\circ} \mathrm{C}$ ).

\begin{tabular}{|c|c|c|c|c|c|c|c|}
\hline \multirow[t]{2}{*}{ Filter } & \multirow{2}{*}{$\begin{array}{c}\text { Wave length } \\
\text { of } \\
\text { maximum } \\
\text { inltration } \\
\lambda \mathrm{m} \mu\end{array}$} & \multicolumn{2}{|c|}{$\begin{array}{l}\text { Soybean protein sol } \\
\text { nitrogen content } \\
1.21 \mathrm{mg} / \mathrm{cc} \text { pH }=6.5\end{array}$} & \multicolumn{2}{|c|}{$\begin{array}{l}\text { Soybean protein sol } \\
\text { nitrogen content } \\
0.61 \mathrm{mg} / \mathrm{cc} \text {. } \mathrm{pH}=6.5\end{array}$} & \multicolumn{2}{|c|}{$\begin{array}{l}\text { Soybeap protein sol } \\
\text { nitrogen content } \\
1.21 \mathrm{mg} / \mathrm{cc} . \mathrm{pH}=6.4\end{array}$} \\
\hline & & I & I $\lambda^{4} \cdot 10^{-13}$ & I & I $\lambda^{13} \cdot 10^{-13}$ & I & $I \lambda^{4} \cdot 10^{-13}$ \\
\hline $\mathrm{L}_{1}$ & 590 & 270.3 & 3.3 & 208.3 & 2.5 & 285.7 & 3.5 \\
\hline $\mathrm{S}_{57}$ & 575 & 344.8 & 3.7 & 232.6 & 2.5 & 370.4 & 3.9 \\
\hline $\mathrm{S}_{5}$ & 531 & 416.7 & 3.3 & 312.5 & 2.4 & 444.4 & 3.6 \\
\hline$S_{30}$ & 494 & 490.2 & 2.4 & 416.7 & 2.0 & 666.7 & 3.2 \\
\hline$S_{47}$ & 465 & 500.0 & 2.3 & 434.8 & 2.0 & 645.2 & 3.0 \\
\hline $\mathrm{S}_{43}$ & 438 & - & - & 487.8 & 1.8 & 952.4 & 3.5 \\
\hline \multicolumn{3}{|c|}{ Mean value of $I \lambda^{4} \cdot 10^{-13}$} & 3.2 & & 2.3 & & 3.5 \\
\hline
\end{tabular}

II. Flocculation of soy bean protion by the addition of salt.

By the addition of the electrolytes, such as ammonium sulfate, sodium sulfate, sodium chloride, to the soy bean protein sol, a flocculation appears at a certain concentration of salt lower than that needed for salting out. Between these two concentrations of salt, peptization takes place and the protein particles disperse in the high degree, 
Table 2. Effect of salts to soy bean protein sol and soy bean albumin sol.

$$
\text { Soybean protein sol }
$$

nitrogen content $\cdot 0.235 \sim 0.245 \mathrm{mg} / \mathrm{cc} . \quad \mathrm{pH}=6.4$

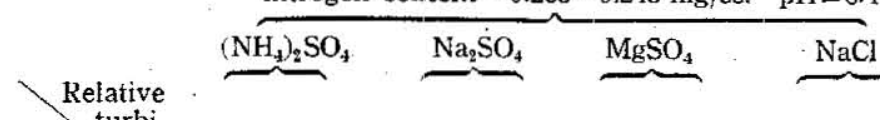

$$
\text { Conc. dity }
$$

Soybean albumin sol nitrogen content $0.03 \mathrm{mg} / \mathrm{cc} . \mathrm{pH}=6.4$ $(\overbrace{\left(\mathrm{NH}_{4}\right)_{2} \mathrm{SO}_{4}}^{\mathrm{Na}_{2} \mathrm{SO}_{4}} \overbrace{}^{\mathrm{NaCl}}$

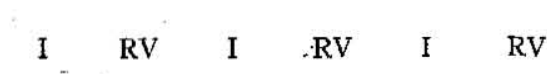

$\begin{array}{llllll}53 & 100 \quad 53 \quad 100 \quad 53 & 100\end{array}$

$\begin{array}{llllll}52 & 98 & 51 & 96 & 52 & 98\end{array}$

$\begin{array}{llllll}51 & 97 & 49 & 92 & 52 & 98\end{array}$

$\begin{array}{llllll}50 & 97 & 47 & 89 & 50 & 94\end{array}$

$\begin{array}{llllll}50 & 97 & 31 & 59 & 39 & 74\end{array}$

$\begin{array}{llllll}50 & 97 & 27 & 51 & 37 & 70\end{array}$

$\begin{array}{llllll}42 & 79 & 28 & 53 & 34 & 64\end{array}$

$\begin{array}{lllllll}30 & 54 & 29 & 55 & 37 & 70\end{array}$

$\begin{array}{llllll}24 & 45 & 31 & 59 & 39 & 74\end{array}$

$\begin{array}{llllll}18 & 34 & 34 & 64 & 42 & 79\end{array}$

$\begin{array}{llllll}18 & 34 & 50 & 94 & 47 & 89\end{array}$ 
To $10 \mathrm{cc}$ of soy bean protein sol prepared by the method previously mentioned add varying volumes of 2 to $0.002 \mathrm{Mol}$. solution of neutral salts, and increase the total volume to $50 \mathrm{cc}$ with distilled water. The protein sols having 0.001 to $1.0 \mathrm{Mol}$. concentration of salt are then obtained.

Their turbidities are measured by means of Pulfrich's Step Photometer (for turbidity) in $30 \mathrm{~min}$. after adding salt. The results obtained are shown in Table 2 and illustrated in Fig. 1.

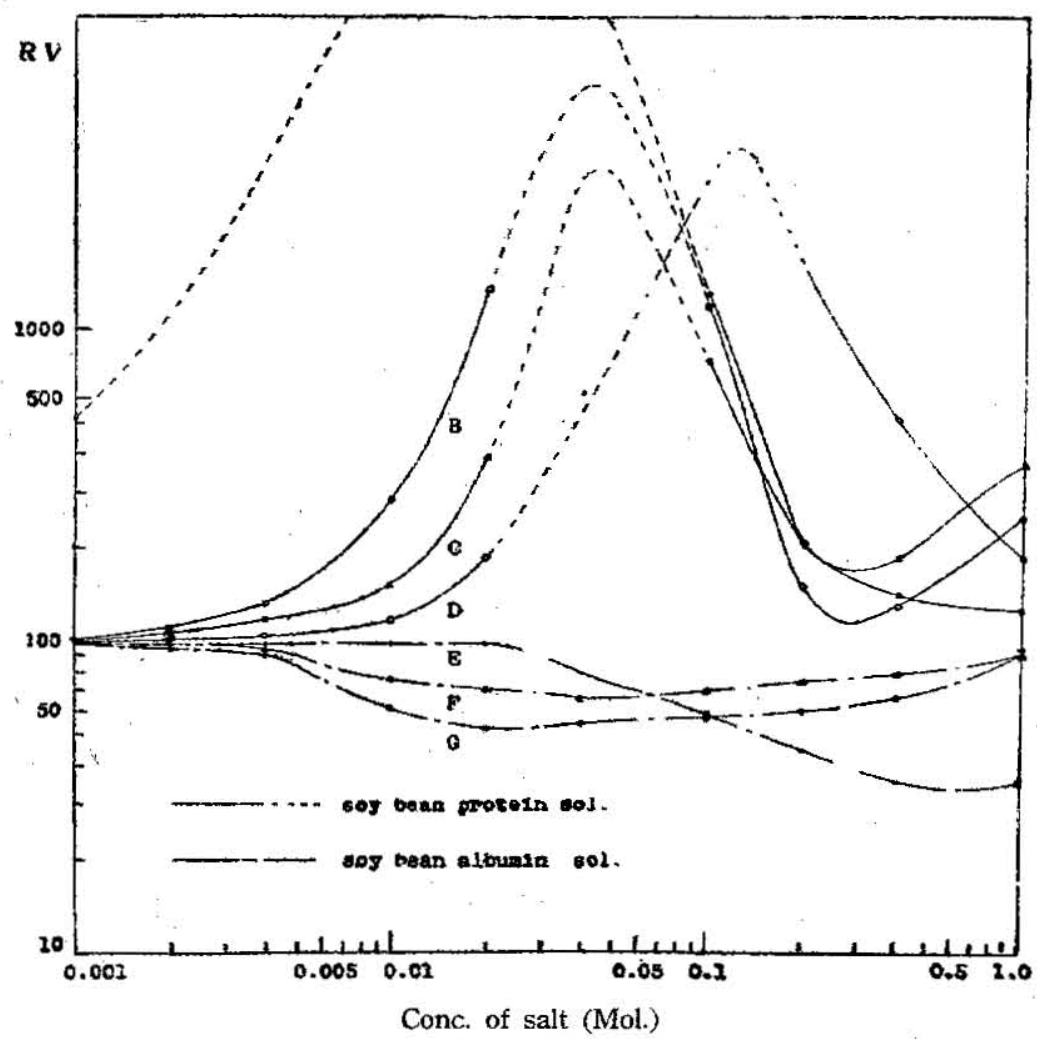

Fig. 1. Effect of salt to soy bean protein sol and albumin.
$\mathrm{A}: \mathrm{MgSO}_{4}$
B : $\left(\mathrm{NH}_{4}\right)_{2} \mathrm{SO}_{4}$
C: $\mathrm{Na}_{2} \mathrm{SO}_{4}$
$\mathrm{D}: \mathrm{NaCl}$
$\mathrm{E}:\left(\mathrm{NH}_{4}\right)_{2} \mathrm{SO}_{4}$
$\mathrm{F}: \mathrm{NaCl}$
$\mathrm{G}: \mathrm{Na}_{2} \mathrm{SO}_{4}$ 


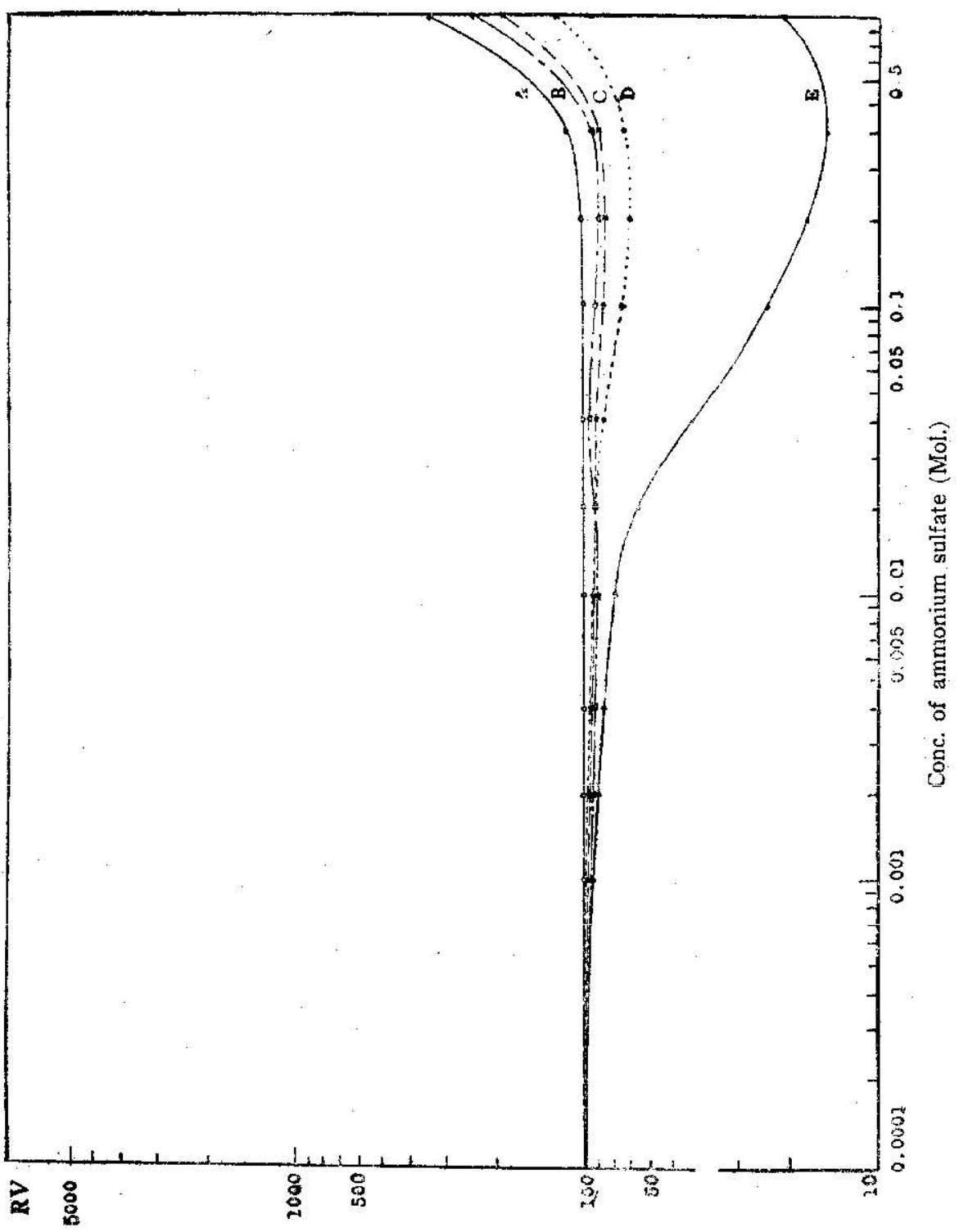

Fig. 2. Effect of $\mathrm{NaCl}$.
A: $10 \% \mathrm{NaCl}$
B : $5 \% \mathrm{NaCl}$
C: $4 \% \mathrm{NaCl}$
D : $2.5 \% \mathrm{NaCl}$
$\mathrm{E}: 2 \% \mathrm{NaCl}$ 
It will be noticed that the gradual increase in the relative turbidity after the addition of salt is followed with the abrupt increase to a maximum, giving rise to flocculation. Then the rapid peptization takes place, followed with salting out.

In the case of adding ammonium sulfate, for instance, the relative turbidity of sol increases gradually until 0.01 Mol. concentration of salt and reaches its maximum value at about $0.04 \mathrm{Mol}$. Salting out takes place in concentration greater than $0.4 \mathrm{Mol}$. These turbidity curves are given in similar way by various salts, but, of course, the point bf flocculation varies with the kinds of salt.

The flocculation occurs also in 10 to 20 times diluted sol (see Table 5). It seemes to indicate that the concentration of electrolytes originally contained in the protein sol is not inherent to the flocculation. On the other hand, the series of protein sol, to which $\mathrm{NaCl}$ has been previously added up to $2.5 \%, 5 \%$ and $10 \%$ respectively, give no flocculation by adding a solution of ammonium sulfate which containes the respective concentration of $\mathrm{NaCl}$. (see Fig. 2). It is considered that by adding $\mathrm{NaCl}$ the unsaturated protein particle adsorbs $\mathrm{Na}$ ion and changes into saturated colloid, thus resulting in the increase of bound-water to maximum value and dispersal in stable state. Even if the substitution of ion between $\mathrm{Na}$ and $\mathrm{NH}_{4}$ takes place by adding ammonium sulfate, the protein particle will be kept in stable state and give no flocculation.

From these two experiments above mentioned, it will be seen that the greater parts of the protein particles are in unsaturated state. The fact that albumin does not show, flocculation by adding such a small quantity of salt, makes us conclude that this flocculation takes place chiefly due to unstable dispersion state of globulin. Even though globulin gets into solution by combining with the inorganic salts in soy bean and. increases its stability in solution by combining with albumin, yet it exists in relatively unstable state, i.e., in unsaturated colloidal state. This unstable globulin is further protected by this combined albumin from the action of salt, that is, from the attack of salt to that governing the stability of globulin.

The addition of salt results in the breakdown of the electrical potential as well as the decrease of bound-water, which cause the lowering of the stability of protein particles, especially of globulin. 
But at the same time there is a resistance to the change of stability, which is given by albumin.

The change of the electrical condition of protein particle, due to the substitution of adsorbed ion, the change of Donnan potential and the change of ionic activity, can be demonstrated by the change in hydration as well as the change in viscosity of sol. ${ }^{8)}$ The flocculation, therefore, will be explained more in detail by measuring the viscosity of sol".

The change in viscosity by the addition of ammonium sulfate has been shown by the ratio, $\left(\eta_{s+e}-\eta_{e}\right) / \eta_{e}$, in Table 3 and Fig. 3.

Table 3. Change of viscosity and that of $\mathrm{pH}$ of soy bean protein sol by adding ammonium sulfate.

\begin{tabular}{|c|c|c|c|c|c|c|c|c|}
\hline $\begin{array}{l}\text { Concen- } \\
\text { tration } \\
\text { of salt } \\
\text { Mol./L }\end{array}$ & I & $\mathrm{pH}$ & $\eta_{s} / \eta_{w}$ & $\eta_{s}+e / \eta_{e}$ & $\frac{\eta_{s+e} / \eta_{e}}{\eta_{e} / \eta_{w}} \cdot 100$ & $\frac{\eta_{s}-\eta_{w}}{\eta_{w}}$ & & $\frac{-\eta_{e}}{e}$ \\
\hline 0.000 & 78 & 6.40 & 1.0069 & & 100.0 & 0.0069 & & 100 \\
\hline 0.001 & 79 & 6.72 & & 1.0197 & 101.3 & & $0 ; 0197$ & 281 \\
\hline 0.002 & 86 & 6.72 & & 1.0245 & 101.7 & & 0,0245 & 350 \\
\hline 0.004 & 100 & 7.03 & & 1.0250 & 101.8 & & 0.0250 & 357 \\
\hline 0.010 & 222 & 7.03 & & 1.0257 & 101.9 & & 0.0257 & 367 \\
\hline 0.020 & 1111 & 7.04 & & 1.0254 & 101.8 & & 0.0254 & 363 \\
\hline 0.040 & 1428 & 7.05 & & 1.2331 & 122.5 & & 0.2331 & 3329 \\
\hline 0.100 & 909 & 6.98 & & 1.0130 & 100.6 & & 0.0130 & 186 \\
\hline 0.200 & 124 & 6.98 & & 1.0102 & 100.3 & & 0.0102 & 146 \\
\hline 0.400 & 100 & 6.98 & & 1.0119 & 100.5 & & 0.0119 & 170 \\
\hline 1.000 & 192 & 6.98 & & 1.0118 & 101.1 & & 0.0178 & 254 \\
\hline 1.200 & - & 6.98 & & 1.0232 & 101.6 & & 0.0232 & 331 \\
\hline
\end{tabular}

On adding ammonium sulfate, the relative viscosity of sol hardly increases until the concentration of salt reaches to $0.04 \mathrm{Mol}$, except for the initial little increase, but at the point of flocculation it increases suddenly to a maximum high value and then falls down giving rise to peptization. A salting out will follow with a gradual increase in the viscosity. The change of $\mathrm{pH}$ of sol parallels the change of viscosity, but not in such great magnitude.

The initial increase in viscosity is caused by the rapid adsorption of ammonium ion by unsaturated protein particle. At the same time, the ionic substitution will occur between adsorbed and added ions. Inherently the soy bean protein particle seems to be similar to K-colloid, judging from the quantity of electrolytes of soy bean. The adsorption power of ammonium ion by protein 


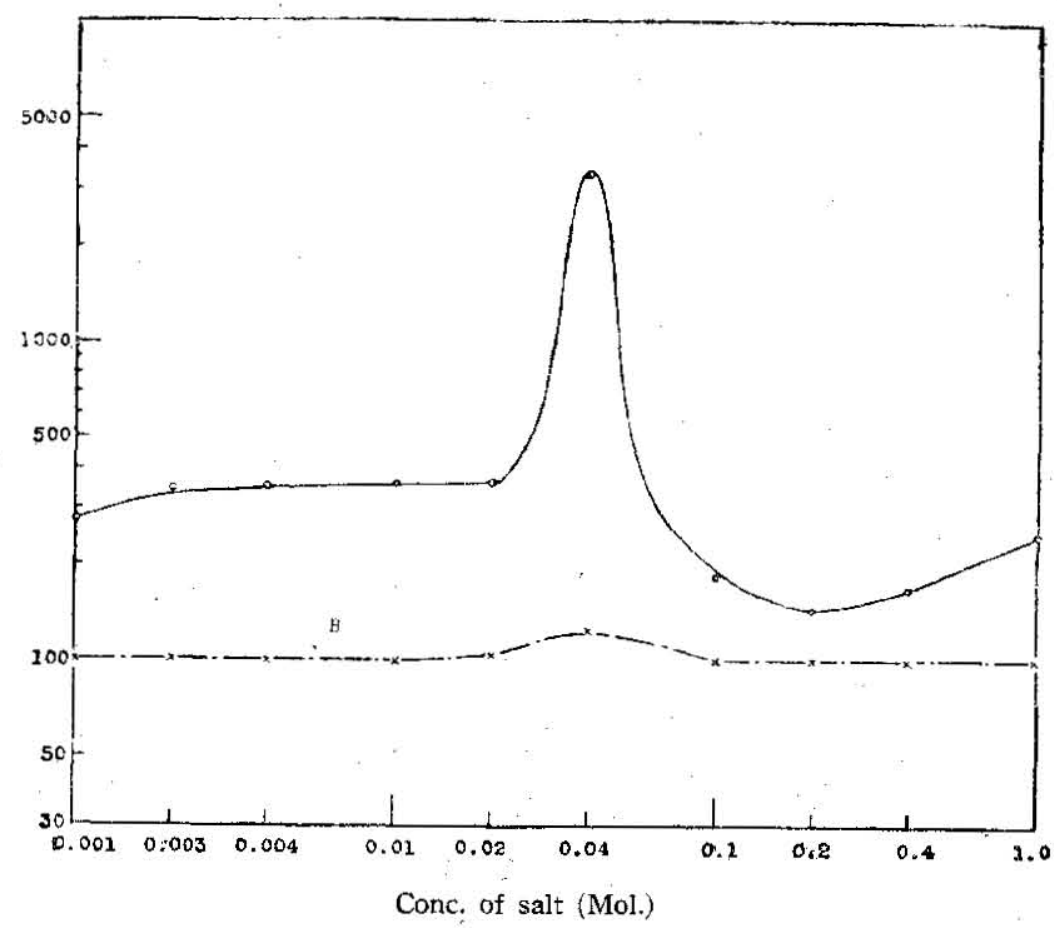

Fig. 3. Change in viscosity.

$$
\text { A: } \frac{\eta_{s+e}-\eta_{e}}{\eta_{e}} \cdot 100 \quad \text { B: } \frac{\frac{\eta_{s+e}}{\eta_{e}}}{\frac{\eta_{s}}{\eta_{w}}} \cdot 100
$$

particle is so much stronger than that of potassium that the ionic substitution occurs between them. This phenomenon may be continued to the end of ionic substitution and until finally the colloid becomes saturated with ammonium ion. Since the hydration of ammonium ion is smaller than that of potassium ion, the decrease of hydration of protein particle must accompany the substitution of ion. ${ }^{8}$ The changing into saturated colloid, will results in the depression of Donnan potential and ionic activity which causes the decrease of total potential of protein' micelle. But all of those tendencies to lower the hydration of particle appeared to be negligible compared to the increase of hydration by adsorbed albumin. In this connection the combination of albumin means the increase of bound-water. Nevertheless, owing to the change of those electrical conditions, ${ }^{9)}$ the total potential of micelle becomes lower. 
The bound-water and combined albumin separate gradually and partially from globulin. Some of those globulin particles which repel each other adsorb together, resulting in the lowering of electrical resistance. And so a large particle is adsorbed by a smaller one. Thus the increase in viscosity due to the enlargement of volume of particle by aggregation will counter balance the decrease in viscosity caused by the depression of hydration of particlę.

In this way the viscosity of sol appears to remain constant. But at $0.04 \mathrm{Mol}$. concentration of ammonium sulfate increases the viscosity rapidly and the flocculation occurs. This will be accounted for by the breakdown of the combination of albumin and globulin. In consequence, parts of globulin are subjected to the attack of salt. This leads to the rapid flocculation of globulin particle. Then the viscosity falls down very rapidly and this means so-called peptization. At this point the potential of particle falls down below the critical potential and albumin will separate completely from globulin. Over this concentration of salt the combination of globulin with albumin will be completely destroyed and globulin will become sensitive to salts. Adding more quantities of salt increases the viscosity. This will mean slow aggregation.

Because of this action, we conclude that albumin plays an important rôle in flocculation and that globulin will become just as hydrated. It will be presumed, accordingly, that the flocculation will take place in a different manner depending upon the proportion of albumin to globulin. To ascertain this assumption, the following experiment has been carried out.

III. The influence of the proportion of albumin to globulin upon the effects of salt.

To make clear the influence of the ratio between globulin and albumin upon the effect of salt, soy bean albumin was added to the soy bean protein sol in different concentrations and the effect of ammonium sulfate upon them has been observed. The soy bean albumin was prepared by the following method. The soy bean protein sol has been subjected to dialysis for 2 days against water using collodion membrane. The precipitated globulin was separated by centrifuge and supernatant albumin fraction has further been 
Table 4. Influence of ratio $\frac{\text { globulin }}{\text { albumin }}$ upon the effect of ammonium sulfate.

\begin{tabular}{|c|c|c|c|c|c|c|c|c|c|c|c|c|}
\hline $\begin{array}{c}\text { Number of sol } \\
\text { The composition } \\
\text { of sol }\end{array}$ & \multicolumn{2}{|c|}{$\begin{array}{c}\text { I } \\
\text { Soybean protein } \\
\text { sol + albumin } \\
\text { fraction }\end{array}$} & \multicolumn{2}{|c|}{$\begin{array}{l}\text { II } \\
\text { Soybean protein } \\
\text { sol+albumin } \\
\text { fraction }\end{array}$} & \multicolumn{2}{|c|}{$\begin{array}{l}\text { III } \\
\text { Soybean protein } \\
\text { sol + albumin } \\
\text { fraction }\end{array}$} & \multicolumn{2}{|c|}{$\begin{array}{l}\text { IV } \\
\text { Soybean protein } \\
\text { sol + albumin } \\
\text { fraction }\end{array}$} & \multicolumn{2}{|c|}{$\begin{array}{c}\mathrm{V} \\
\text { Soybean protein } \\
\text { sol (original) }\end{array}$} & \multicolumn{2}{|c|}{$\begin{array}{l}\text { VI } \\
\text { Soybean proteir } \\
\text { sol (10 times } \\
\text { diluted }\end{array}$} \\
\hline Nitrogen $\mathrm{mg} / \mathrm{cc}$ & \multicolumn{2}{|c|}{0.021} & \multicolumn{2}{|c|}{0.041} & \multicolumn{2}{|c|}{0.085} & \multicolumn{2}{|c|}{0.182} & \multicolumn{2}{|c|}{0.285} & \multicolumn{2}{|c|}{0.028} \\
\hline Ratio, $\frac{\text { globulin }}{\text { albumin }}$ & \multicolumn{2}{|c|}{0.02} & \multicolumn{2}{|c|}{1.83} & \multicolumn{2}{|c|}{5.12} & \multicolumn{2}{|c|}{10.51} & \multicolumn{2}{|c|}{13.83} & \multicolumn{2}{|c|}{13.83} \\
\hline $\begin{array}{l}\text { Conc. of turbid } \\
\text { salt (Mol.) }\end{array}$ & I & $\mathrm{RV}$ & I & RV & I & RV & I & $\mathrm{RV}$ & I & $\widehat{R V}$ & I & $\mathrm{RV}$ \\
\hline 0.000 & 89 & 100 & 87 & 100 & 80 & 100 & 82 & 100 & 78 & 100 & 15 & 100 \\
\hline 0.001 & 87 & 97.7 & 85 & 97.7 & 65 & 81.3 & 85 & 103.7 & 79 & 101.1 & 15 & 100 \\
\hline 0.002 & 86 & 96.6 & 77 & 88.5 & 59 & 73.8 & 86 & 104.9 & 86 & 110.0 & 15 & 100 \\
\hline 0.004 & 86 & 96.6 & 32 & 36.8 & 48 & 60.0 & 94 & 114.7 & 100 & 128.0 & 15.5 & 103.4 \\
\hline 0.010 & 86 & 96.6 & 29 & 33.3 & 57 & 71.3 & 143 & 174.2 & 222 & 284.2 & 20 & 133.4 \\
\hline 0.020 & 86 & 96.6 & 80 & 91.9 & 263 & 329.0 & 556 & 677.8 & 1111 & 1422.1 & 77 & 513.6 \\
\hline 0.040 & 70 & 78.6 & 250 & 287.3 & .667 & 833.4 & 1250 & 1525.0 & 1428 & 1827.8 & 263.2 & 1755.6 \\
\hline 0.100 & 45 & 50.5 & 189 & 216.8 & 435 & 543.5 & 833 & 1016.6 & 909 & 1163.5 & 169.5 & 1130.6 \\
\hline 0.200 & 15 & 16.8 & 32 & 36.8 & 69 & 86.3 & 164 & 226.8 & 124 & 158.7 & 34 & 226.8 \\
\hline 0.400 & 12 & 13.5 & 29 & 33.5 & 57 & 71.3 & 122 & 140.1 & 100 & 128.0 & 21 & 140.0 \\
\hline 1.000 & 30 & 33.7 & 45 & 51.7 & 93 & 116.3 & 183 & 220.1 & 192 & 245.8 & 33 & 220.1 \\
\hline
\end{tabular}




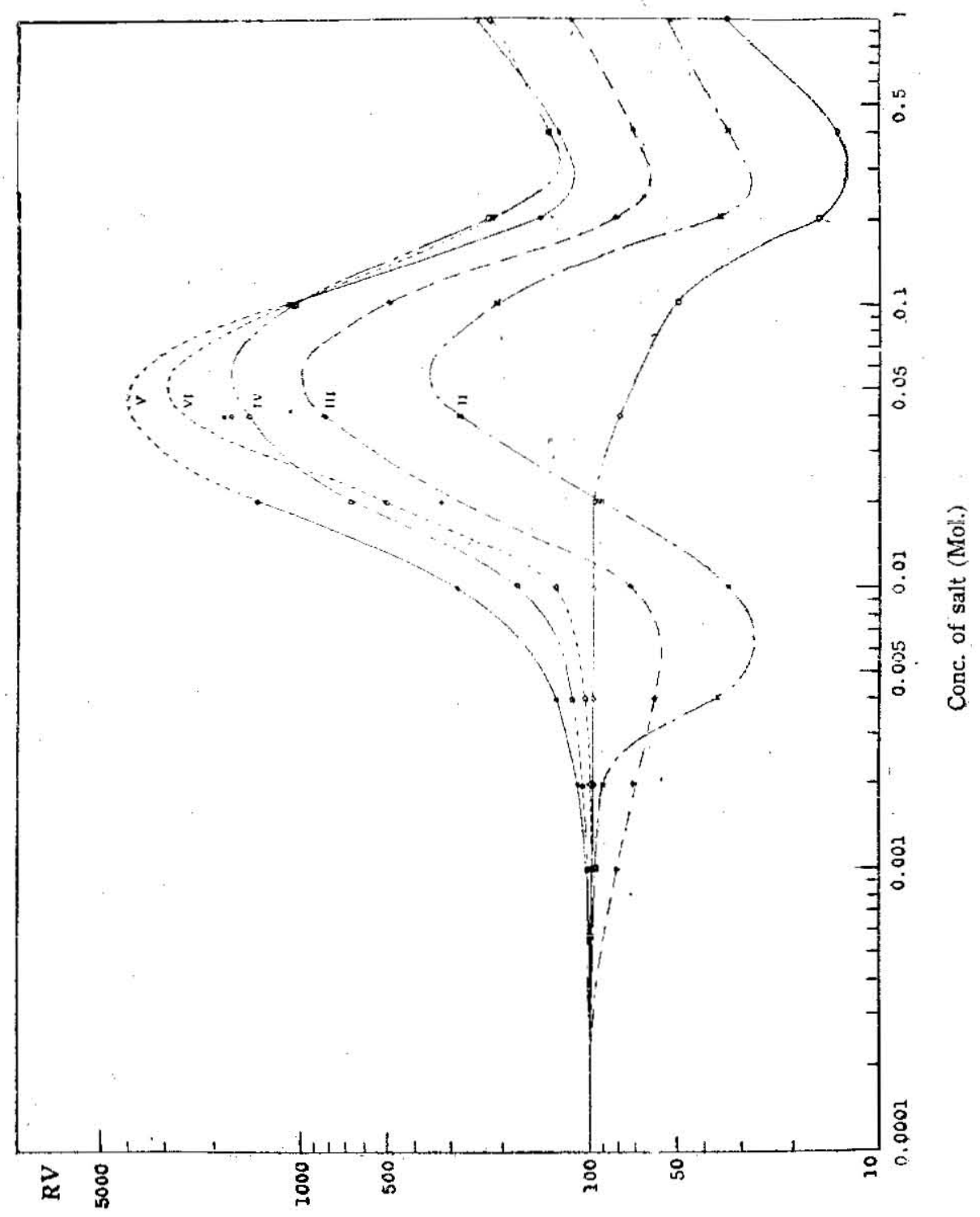

Fig. 4. Influence of globulin/albumin ratio upon the effect of ammonium sulfate to soy bean protein sol. 
subjected to dialysis for 2 days against distilled water. The precipitated globulin was again centrifuged off and clear albumin fraction was obtained by filtration through filter pulp.

The determination of the ratio between globulin and albumin was made by the method by Muramatsu. ${ }^{10 \text {, }}$

Experimental results were given in Table 4 and Fig. 4.

The flocculation occurs in a different manner on changing the proportion of albumin to globulin. From the fact*. that there is no change of colloidal state in diluted sol due to adding albumin fraction, it will be clear that the decrease of nitrogen content gives no effect upon the flocculation. This phenomenon may be accounted for by the increase of stability of globulin due to the protective action of albumin. The following data will show clearly the intimate relation between $\mathrm{RV}$ and the proportion of globulin to albumin at $0.04 \mathrm{Mol}$. ammonium sulfate, that is, in a point at which the dispersity of protein particles is minimum.

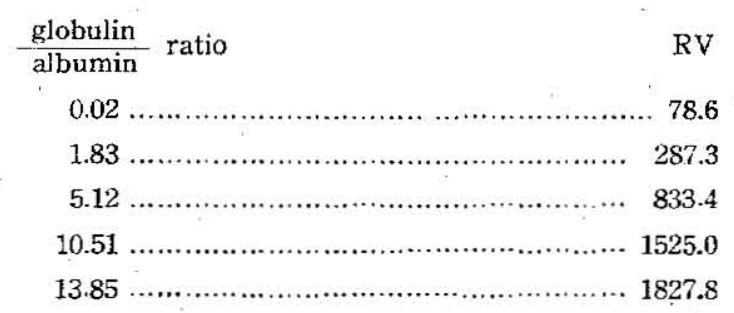

As the ratio changes, there also occurs the flocculation in a different manner. When the ratio falls down to 0.02 , almost no flocculation takes place. The above result apparently reveals the important rôle of albumin in the flocculation. In this connection it will naturally be expected that, in place of soy bean albumin, egg albumin will have the same effect on the flocculation. Practically the same results were obtained with egg albumin, as is shown in Table 5 and Fig. 5. Egg albumin behaves in a manner to protect soy bean protein from the influence of salt.

In conclusion, it is a remarkable fact regarding the protective action of protein, that serum albumin as well as egg albumin

* That the dilution due to the addition of albumin fraction gives no influence upon the effect of ammonium sulfate, was ascertained by examining the effect of salt on the 10 or 20 times diluted soy bean protein sol. See Tab. 4 \& 5 . 
Table 5. Effect of egg albumin on the flocculation of soy bean protein by the addition of sodium sulfate.

Number of sol

The composition of sol

Nitrogen, $\mathrm{mg} / \mathrm{cc}$.

Ratio, $\frac{\text { globulin }}{\text { albumin }}$

Relative

Conc. of turbidi

sảit (Múul.)

0.000

0.001

0.002

0.004

0.010

$0.0 \overline{20}$

0.040

0.100

0.200

0.400

1.000
I

lbumine

$$
\text { sol }
$$

0.142

0.00

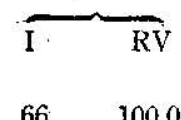

66

65

65

64$$
64
$$$$
63
$$$$
62
$$

55

52

52

54

59

74
II

Soybean protein Soybean protein Soybean protein sol +egg albumin sol

0.146

0.09

sol+egg
albumin sol

0.162

0.34

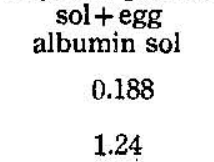

$\mathrm{V}$

Soybean protein

sol

0.285

13.83

$$
\text { VI }
$$

VII

Soybean protein Soybean protein sol (10 times sol (20 times diluted) diluted)

0.029

0.014

13.83

13.83
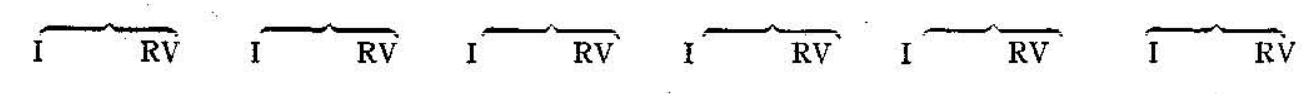

$112 \quad 100.0 \quad 106$

$100 \quad 100 \quad 100$

$89 \quad 100$

$21 \quad 100$

15

100

$\begin{array}{llll}98.5 & 111 & 99.4 & 104\end{array}$

$\begin{array}{lll}97.9 & 98 \quad 98\end{array}$

94

105.6

112.3

$\begin{array}{llll}98.5 & 106 & 95.7 & 102\end{array}$

$96.0 \quad 95$

$93.0 \quad 94$

$92.0 \quad 10$

95

$97.0 \quad 104$

$93.7 \quad 99$

94

100

102

112.3

114.5

137.0

374.3

333

$863.8 \quad 179 \quad 851$

$\begin{array}{lllll}591.0 & 143 & 680 & 101 & 673\end{array}$

$\begin{array}{lllll}167.6 & 31 & 148 & 21 & 140\end{array}$

$\begin{array}{lllll}167.6 & 35 & 167 & 23 & 153\end{array}$

$\begin{array}{lllll}510.4 & 62 & 295 & 47 & 313\end{array}$ 


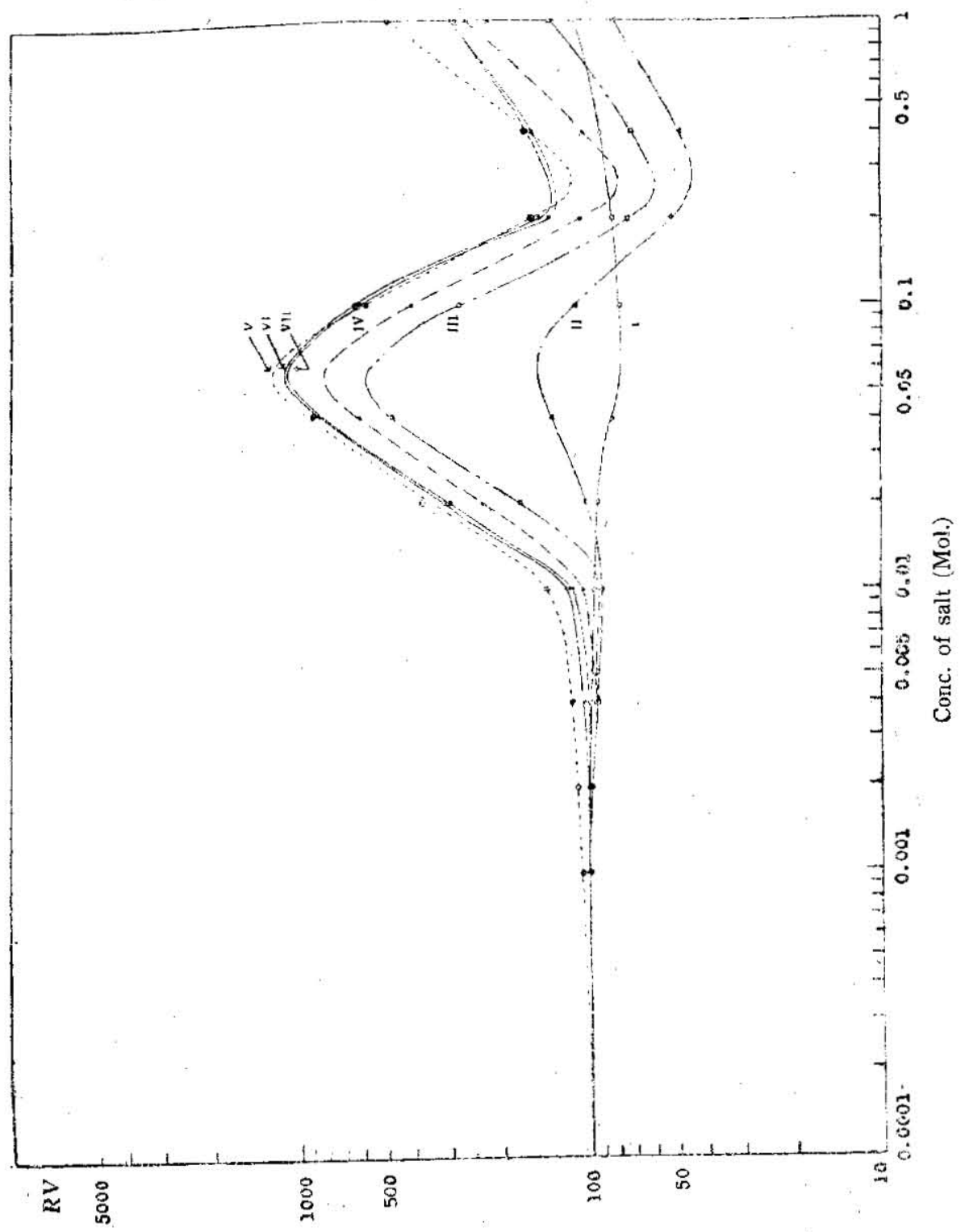

Fig. 5. Effect of egg-albumin to the flocculation of suy bean protein sol by $\mathrm{Na}_{2} \mathrm{SO}_{3}$. 
will be split by the action of clupein, ${ }^{(1)}$ and also that in serum the desaggregation of globulin particle will take place by the action of albumin, as has been reported by McFarlane. ${ }^{22}$. This breaking of the larger protein molecule by the action of smaller one may have an important rôle in protective action. In other words, the protective action may take place by the desaggregation of large protein molecule, thus bringing the unstable state of large molecule into the stable one. It is not yet clear whether the protective action of albumin is due to the combination with globulin or due to the desaggregation of globulin.

\section{SUMMARY}

On adding neutral salt, such as ammonium sulfate, sodium sulfate and sodium chloride, to the soy bean protein sol, flocculation occurs in about $0.04 \mathrm{Mol}$. concentration of salt. It seems that this phenomenon is caused chiefly by globulin which is dispersed in relatively unstable state. Albumin does not flocculate at such a concentration, but yet it plays an important rôle in protecting globulin against the flocculation. The flocculation occurs in a different manner depending on varying proportion of albumin to gobulin. This will be explained by the protective action of albumin against the flocculution of globulin. In this connection egg-albumin has also the same effect upon the flocculation. The mechanism of this protective action may be postulated as follows: the adsorbed albumin plays the same rôle as bound water, that is, albumin combines with globulin and protects it from the action of salt in such a way as to give the protein micelle greater hydration, higher potential and more stability against salt.

In conclusion, the author wishes to express his hearty thanks to Dr. Seiichi Izume at Central Laboratory of S.M.R., Professor Yasuyoshi Oshima and Professor Tetsuo Tomiyama for their helpful advice., 


\section{REFERENCÉS}

1. J. Lloyd: Chemistry of the protein, (1938) 335,401 . W. Pauli \& E. Valko: Elektrochemie der Kolloid, (1929) 454, 167.

2. K. Plötner: Biochem. Z., 286, 279 (1936).

3. J. Alexander: Colloid Chemistry, Theoritical \& Applied, 1, 69 (1929).

4. M. Funatsu: J. Agr. Chem. Soc. Japan, 18, 47 (1941).

5. H. R. Kruyt \& H. G. Bungenburg de Jong: Kolloidchem. Beih., 28, 1, 407 (1929).

6. S. Mattson: Soil Sci., 25, 673 (1928).

7. L. D. Baber: Soil Sci., 29, 291 (1930).

8. G. H. Riesenfeld \& B. Reinhold: Z. physik. Chem., 66, 672 (1909).

9. F. Tuolira: Kolloidchem. Beih., 27, 76 (1928). R. Gallay: Kolloidchem. Beih., 21, 431 (1925).

10. S. Muramatsu: J. Chem. Tokyo, Japan, 41, 311 (1920).

11. The Svedberg: Chem. Rev., 20, 81 (1936).

12. A. S. MacFarlane: Biochem. J., 29, 407 (1935). 